\title{
Evaluation of Anthelmintic Resistance of Benzimidazole and Levamisole on Gastrointestinal Nematode Parasites of Cattle
}

\author{
D. Choudhury ${ }^{1}$ and K. H. Bulbul ${ }^{2 *}$ \\ ${ }^{1}$ Department of Veterinary Parasitology, Lakhimpur College of Veterinary Science, \\ AAU, Joyhing - 787051, India \\ ${ }^{2}$ Division of Veterinary Parasitology, F.V.Sc. \& A.H., SKUAST-K, Shuhama, India \\ *Corresponding author
}

\section{A B S T R A C T}

\begin{tabular}{l}
\hline Ke y w o r d s \\
Anthelmintic \\
resistance, \\
Benzimidazole, \\
Levamisole, \\
FECRT, Cattle \\
\hline Article Info \\
\hline $\begin{array}{l}\text { Accepted: } \\
\text { 10 July } 2020 \\
\text { Available Online: } \\
10 \text { August } 2020\end{array}$ \\
\hline
\end{tabular}

Gastrointestinal nematodes (GINs) resistant to anthelmintics have been reported in several regions of India which may be associated with economic losses for the cattle industry. This study aimed to evaluate the anthelmintic resistance (AR) for gastrointestinal nematodes from naturally infected cattle in Assam to several commercially available anthelmintics like fenbendazole, albendazole and levamisole. The faecal samples were collected per rectum from 325 cattle to screen for detection of GINs and examined qualitatively by floatation and sedimentation technique and quantitively by Stoll's egg counting method. The parasites found positive were Haemonchus, Trichostrongylus, Oesophagostomum, Cooperia and Mecistocirus genera. To evaluate AR by FECRT, 24 animals were randomly selected irrespective of sex and age having EPG > 200 then divided into four groups consisting of six animals in each group before treatment. The first, second and third group was treated with fenbendazole (@ $5 \mathrm{mg} / \mathrm{kg}$ ), albendazole (@ $7.5 \mathrm{mg} / \mathrm{kg}$ ) and levamisole (@ $7.5 \mathrm{mg} / \mathrm{kg}$ ) body weight, respectively and the fourth group was kept as infected untreated control. Faecal samples were collected per-rectally on $0^{\text {th }}$ day (pre-treatment) and 10 and $14^{\text {th }}$ day post-treatment from animals of all groups and individual faecal egg counts were determined by Stooll's egg counting technique. The study revealed FECR\% of $100.00,85.00$ and $90.00 \%$ in animals of first, second and third group, respectively. The study indicated that the GINs of cattle have developed BZ resistance and there is need to control it at an earliest with levamisole.

\section{Introduction}

Trichostrongylids, the gastrointestinal nematodes (GINs) play a significant task in production and productivity of cattle by plummeting their milk and milk production due to poor health condition, anorexia, anaemia, diarrhoea etc (Choudhury et al., 2018a). Among Trichostrongylids, Haemonchus, an abomasal nematode plays an important role in immense fiscal losses to livestock through morbidity, mortality, causing decreased reproductive performance, a low growth rate, weight loss, and poor food conversion (De Graef et al., 2013; Bulbul et al., 2015; Bulbul et al., 2016; Allaie et al., 
2018). The favourable weather condition and availability of larval stages on pasture act as predisposing factor for gastrointestinal parasitism throughout the year (Bulbul et al., 2011). The highly efficacious BZ class of anthelmintic (Dorny et al., 1995; Hafiz et al., 2011) and levamisole (imidazothiazoles) (Mason et al., 2006; Choudhury et al., 2018b) are widely used to control the GINs more or less throughout the globe. The nonjudiciously use of BZ drugs used in field condition ensuing in AR throughout the world (Kaplan, 2004; Bulbul et al., 2018) has been detected in parasitic nematodes of livestock since the early 1960s (Conway, 1964; Drudge et al., 1964). ${ }^{\text {] }}$ However, it has been reported from many states in India in sheep, goat and cattle viz. Haryana (Yadav et al., 1993; Singh et al., 1995), Tamil Nadu (Arunachalam et $a l ., 2005)$ and Karnataka (Dhanalakshmi et $a l ., 2003$ ) and in cattle (Yadav and Verma 1997; Choudhury et al., 2018b). Thus spread of anthelmintic resistance has directed to major problems in livestock farming industries worldwide (Kaplan, 2004; Cabaret, 2000; Papadopoulos et al., 2012; TorresAcosta et al., 2012).

Anthelmintic drug resistance has led to the search for alternatives in controlling helminth infections (Ramos et al., 2016). Among the various methods used to detect the $A R$ in livestock (Prichard et al., 1980; Coles et al., 1992; Coles et al., 2006), the faecal egg count reduction test (FECRT), egg hatch assay (EHA) and larval development assay (LDA) have proven to be suitable tests for detecting BZ resistance (Le Jambre, 1976; Coles et al., 1992). FECRT, the commonest nematicide evaluation means (Coles et al., 1992; Coles et al., 2006), has some shortcomings primarily due to the fact that egg count does not correspond to worm burdens. The FECRT can however be standardized by randomization of animals into treatment groups for even dispersion of egg counts and drug effectiveness, accurate dosing to make sure no administered drug is lost, and proper tagging of animals in each treatment group to ensure correct sampling. To effectively manage roundworm parasites infection in cattle the study was carried out to evaluate the AR against naturally infected GINs in cattle employing FECRT.

\section{Materials and Methods}

A total of 146 cattle were selected irrespective of age and sex from organized farm of Assam to screen the GIN infections. The collected faecal samples were brought to the laboratory and proceed to record the prevalence of GINs by the floatation technique and sedimentation technique by qualitatively and quantitively by Stoll's technique (Soulsby, 1982). After ascertaining the parasitic load (EPG), the therapeutic study was performed as per below mentioned.

\section{Therapeutic study}

To evaluate the anthelmintic resistance the animals were then divided into four groups irrespective sex and age having EPG $\geq 200$ consisting of six animals in each group before treatment. The first group was treated with fenbendazole @ $5 \mathrm{mg} / \mathrm{kg}$ body weight; second group was treated with albendazole @ 7.5 $\mathrm{mg} / \mathrm{kg}$ body weight; third group was treated with levamisole @ $7.5 \mathrm{mg} / \mathrm{kg}$ body weight and the fourth group was kept as infected untreated control. The drugs were given orally in first three groups of animals. Faecal samples were collected per-rectally on the $0^{\text {th }}$ day (pre-treatment) and 10 and $14^{\text {th }}$ day of post-treatment from animals of all groups and faecal egg counts of an individual sample were determined by Modified McMaster technique. The FECR\% of the drugs and AR were performed by employing the FECRT as per the standard method (Coles et al., 1992; Coles et al., 2006). 


\section{Results and Discussion}

The parasitic ova found positive were Haemonchus, Trichostrongylus, Oesophagostomum, Cooperia and Mecistocirus genera based on egg characteristics. The prevalence of GINs in cattle in organised farm was found to be $41 \%$ (58 out of 146). The worldwide distributed GI nematodosis also occurs in Assam (Choudhury et al., 2018a) due to the hot and humid sub-tropical climate which always favours to develop and survive the preparasitic stages of nematodes throughout the year especially in pre-monsoon, monsoon and post-monsoon (Bulbul et al., 2016) hence infective larvae are available on the pasture (Bulbul et al., 2011) as a source of infection (Das et al., 2016). Strongyloides, Trichostrongylus, Haemonchus, Oesophagostomum, Cooperia, Bunostomum and Mecistocirrus are the most important genera prevalent in cattle of North-eastern India (Latha et al., 2013; Das et al., 2015) including other parts of the country (Bulbul et al., 2014; Allaie et al., 2018) like our observations in the present study.

\section{Faecal egg count reduction test}

In the first group mean EPG before treatment was found to be 300 . After 10 and 14 days of treatment mean EPG was found to be 0 . The FECRT (\%) was found to be 100 after treatment of 10 and 14 days. In the second group mean EPG before treatment was found to be 267. After 10 and 14 days of treatment mean EPG was found to be 50. The FECRT (\%) was found to be 85 after treatment of 10 and 14 days. From the data calculated according to the formula of FECRT, it was found that the first group that was found to be $100 \%$ effective where as the second and third group that are treated with albendazole and levamisole had found to develop resistance. When administered BZs, it inhibit the polymerisation of $\alpha$ and $\beta$-tubulin dimmers to microtubules (Sangster et al., 1985) and restrain the glucose uptake leading to death of worms (Lacey, 1988). Therefore, the BZs are administered to exert their effect on the parasites by binding to the tubulin protein and preventing its polymerization into microtubules (Lacey and Gill, 1994). The use of chemotherapeutic drugs to control internal and external parasites is a widespread practice in livestock production and several broadspectrum anthelmintics are available in the market for the control of helminthosis. Currently, failure of anthelmintics and reduced efficacy due to resistance of nematodes in cattle are becoming a threat in some countries and are of increasing importance in Indian sub-continent (Bulbul et al., 2018). According to Waller (1987) most of the nematodes of domestic animals have shown resistance to common anthelmintics especially in warm and humid parts of the world and this has been suspected to be due to frequent dosing and poor therapeutic strategies (Waller, 1999; Danquah et al., 2012).

Levamisole, an imidazothiazole derivative, was a good alternative for the treatment of gastrointestinal nematodes at some farms, in line with reports by (Gasbarre, 2014; Choudhury et al., 2018b). Simultaneously, in the third group mean EPG before treatment was found to be 250. After 10 days of treatment mean EPG was found to be 50 and after 14 days of treatment mean EPG was found to be 90 . The FECRT (\%) was found to be 80 and 64 after treatment of 10 and 14 days. While farmers reported knowledge of levamisole in the present study, it was frequently used, indicating high selection pressure. The levamisole compounds act as depolarising neuro-muscular blocking agents in both nematodes and their host. Levamisole acts selectively as a cholinergic agonist at the synaptic and extra synaptic nicotinic 
acetylcholine receptors on nematode muscle cells which cause spastic paralysis of susceptible nematode by selectively gating acetylcholine receptor ion channels on nerve and muscle.

The fourth group which consists of infected untreated control showed the EPG in increasing trends towards the successive days. On 0 day, the mean EPG was found to be 350 and after 10 days it was found to be 433 and after 14 days 483 as previously observed by Choudhury et al., (2018b).

Anthelmintic drugs such as albendazole, ivermectin, and levamisole are used to treat parasitic infection in cattle. The regular use of these drugs and sometimes improper use make the issue of resistance inevitable (Bulbul et al., 2018). According to Shalaby (2013), it has been observed that frequent use of the same group of anthelmintic, use of anthelmintics in suboptimal doses, prophylactic mass treatment of domestic animals, and frequent and continuous use of a single drug have contributed to the widespread development of anthelmintic resistance in helminths as observed in our present investigation.

\section{References}

Allaie, I.M., Shahardar, R.A., Trambo, S.R., Bulbul, K.H., Wani, Z.A. and Khan, A.A. 2018. Prevalence of gastrointestinal nematodes in small ruminants of Kashmir valley. $J$. Entomol. Zool. Stud. 6(2): 2554-2559.

Arunachalam, K., Raman, M., Jayathilakan, N. and Karunanidhi, K. 2005. Multiple anthelmintic resistance in gastrointestinal nematodes from Mecheri sheep in an organized farm in Tamil Nadu. Indian J. Anim. Sci. 75: 203-205.

Bulbul, K.H., Baruah, N. and Saleque A.
2015. Seasonal prevalence of haemonchosis in Beetal goats in an organized farm of Assam. Int. J. Rec. Sci. Res. 6(6):4468-4471.

Bulbul, K.H., Baruah, N. and Saleque, A. 2011. Pasture larval burden of grazing land of goat in Assam during different season. Environment \& Ecol. 29(4):1763-1765.

Bulbul, K.H., Saleque, A., Baruah, N. and Choudhury, D. 2016. Epidemiological studies on haemonchosis in crossbred goats of organized farm in Assam. Vet. Pract. 17(1):25-27.

Bulbul, K.H., Shafi, S.S., Hasin, D., Akand, A.H., Ahmad, N. and Sheikh, I.U. 2018. Impact of anthelmintic against naturally infected gastrointestinal nematodes in ruminants of Budgam District, Jammu and Kashmir, India. Int. J. Curr. Micro. App. Sci. 7(3): 2410-2416

Cabaret, J. 2000. Anthelmintic resistance in goats: from fiction to facts. In: proceedings of the seventh international conference on goats. p- 793-794.

Choudhury, D., Phukan, S.C., Islam, S., Bulbul, K.H. Milli, D.C., Sarmah, R.K. and Baruah, A. 2018a. Prevalence of gastrointestinal nematodosis due to Trichostrongylids in cattle of of organized dairy farm of Assam. J. Entomol. Zool. Stud. 6(4): 1849-18544.

Choudhury, D., Phukan, S.C., Islam, S., Sarmah, R.K., Baruah, A., Milli, D.C. and Bulbul, K.H. 2018b. Diagnosis of anthelmintic resistance against naturally infected gastrointestinal nematodes in cattle of Assam employing FECRT and molecular techniques. J. Entomol. Zool. Stud. 6(2): 2439-2442.

Coles, G.C., Bauer, C., Borgsteede, F.H.M., Geerts, S., Klei, T.R., Taylor, M.A. and Waller, P.J. 1992. World association for the advancement of Veterinary Parasitology (WAAVP) methods for the detection of anthelmintic resistance in 
nematodes of veterinary importance. Vet. Parasitol. 44:35-44.

Coles, G.C., Jackson, F., Pomroy, W.E., Prichard, R.K., Von SamsonHimmelstjerna, G., Silvestre, A., Taylor, M.A. and Vercruysse, J. 2006. The detection of anthelmintic resistance in nematodes of veterinary importance. Vet. Parasitol. 136: 167-185.

Conway, D.P. 1964. Variance in the effectiveness of thiabendazole against Haemonchus contortus in sheep. American J. Vet. Res. 25: 844-846.

Danquah, C.A., Koffuor, G.A. Annan, K and Ketor, E.C. 2012. The anthelmintic activity of Vernonia amygdalina (Asteraceae) and Alstonia boonei De Wild (Apocynaceae). J. Med. Biom. Sci. 1(1): 21-27.

Das, M., Deka, D.K., Islam, S., Sarmah, P.C. and Bhattacharjee, K. 2016. Gastrointestinal nematode larvae in the grazing land of cattle in Guwahati, Assam. Vet. World. 9(12):1343-1347.

Das, M., Deka, D.K., Sarmah, A.K., Sarmah, P.C. and Islam, S. 2015. Gastrointestinal parasitic infections in cattle and swamp buffalo of Guwahati, Assam, India. Indian J. Anim. Res. 3427:1-7.

De Graef, J., Claerebout E. and Geldhof P. 2013. Anthelmintic resistance of gastrointestinal nematodes cattle. Vlaams Diergeneeskd. Tijdschr. 82:113-123.

Dhanalakshmi, H., Jagannath, M.S. and Placid, E.D. 2003. Multiple anthelmintic resistance in gastrointestinal nematodes of sheep. J. Vet. Parasitol.17:89-91.

Dorny, P., Symoens, C., Jalila, A., Vercruysse, J. and Sani, R. 1995. Strongyle infections in sheep and goats under the traditional husbandry system in peninsular Malaysia. Vet. Parasitol. 56:121-136.
Drudge, J.H., Szanto, J., Wyant, Z.N. and Elam, G.W. 1964. Field studies on parasite control of sheep: comparison of thiabendazole, ruelene and phenothiazine. American J. Vet. Res. 25:1512-1518.

Gasbarre L.C. 2014. Anthelmintic resistance in cattle nematodes in the US. Vet. Parasitol. 204:3-11.

Hafiz, A., Akand, A.H. and Bulbul, KH. 2011. Therapeutic efficacy of albendazole against gastrointestinal nematodes in calves. Indian $J$. Vet. Med. 6:33-34.

Kaplan, R.M. 2004. Drug resistance in nematodes of veterinary importance: a status report. Trend Parasitol. 20:477481.

Lacey E. 1988. The role of the cytoskeletal protein, tubulin, in the mode of action and mechanism of drug resistance to benzimidazoles. Int. J. Parasitol.18:885936.

Lacey, E. and Gill, J.H. 1994 Biochemistry of benzimidazole resistance. Acta Trop. 56:245-262.

Laha, R., Das, M. and Goswami A. 2013. Gastrointestinal Parasitic Infections in Organized Cattle Farm of Meghalaya. Vet. World. 6:109-112.

Le Jambre, L.F. 1976. Egg hatch as an in vitro assay of thiabendazole resistance in nematodes. Vet. Parasitol. 2:385-391.

Mason, P.C. and MacKay, C.H. 2006. Field Studies Investigating Anthelmintic Resistance in Young Cattle on Five Farms in New Zealand. New Zealand Vet J. 54(6): 318-22.

Papadopoulos, E., Gallidis, E. and Ptochos, S. 2012. Anthelmintic resistance in sheep in Europe: a selected review. Vet. Parasitol.189:85-88.

Prichard, R.K., Hall, C.A., Kelly, J.D., Martin, I.C.A. and Donald, A.D. 1980. The problem of anthelmintic resistance in nematodes- Review Article. 
Australian Vet. J. 56:239-251.

Ramos, F., Portella, L.P., Rodrigues, F. S., Reginato, C.Z., Potter, L., Cezar, A.S., Sangioni, L.A. and Vogel, F.S.F. 2016. Anthelmintic resistance in gastrointestinal nematodes of beef cattle in the state of Rio Grande do Sul, Brazil. Int. J. Parasitol. Drugs Drug Resist. 6(1): 93-101.

Sangster, N.C., Prichard, R.K. and Lacey, E. 1985. Tubulin and benzimidazoleresistance in Trichostrongylus colubriformis (nematoda). J. Parasitol. 71:645-651.

Shalaby, H.A. 2013. Anthelmintics resistance; how to overcome it? Iranian J. Parasitol. $8(1): 18-32$.

Singh, D., Swarnkar, C.P., Khan, F.A., Srivastava, C.P. and Bhagwan, P.S.K. 1995. Resistance to albendazole in gastrointestinal nematodes of sheep. J. Vet. Parasitol. 9:95-98.

Soulsby, E.J.L.1982. Helminths, Arthropods and protozoa of domesticated animals.
East-West Press Pvt. Ltd. $7^{\text {th }}$ Edn. 1982; pp- 766.

Torres-Acosta, J.F., Mendoza-de-Gives, P., Aguilar-Caballero, A.J. and CuellarOrdaz JA. 2012. Anthelmintic resistance in sheep farms: update of the situation in the American continent. Vet. Parasitol.189:89-96.

Waller, P.J. 1987. Anthelmintic resistance and the future for roundworm control. Vet. Parasitol. 25(2): 177-191.

Waller, P.J. 1999. International approaches to the concept of integrated control of nematode parasites of livestock. Int. J. Parasitol. 29 (1): 155-164.

Yadav, C.L. and Uppal RP.1993. Resistance of caprine Haemonchus contortus against fenbendazole. Indian Vet. J. 70:798-800.

Yadav, C.L. and Verma, S.P.1997. Morantel resistance by Haemonchus placei in cattle. Vet. Rec. 41:499-500.

\section{How to cite this article:}

Choudhury, D. and Bulbul, K. H. 2020. Evaluation of Anthelmintic Resistance of Benzimidazole and Levamisole on Gastrointestinal Nematode Parasites of Cattle. Int.J.Curr.Microbiol.App.Sci. 9(08): 437-442. doi: https://doi.org/10.20546/ijcmas.2020.908.051 